\title{
ANREDERA CORDIFOLIA LEAVES FRACTION AS AN ANTIHYPERLIPIDEMIA
}

\author{
DWINTHA LESTARI ${ }^{1 *}$, ELIN YULINAH SUKANDAR ${ }^{1}$, IRDA FIDRIANNY²
}

${ }^{1}$ Pharmacology-Clinical Pharmacy Research Group, School of Pharmacy, Bandung Institute of Technology, Indonesia. ${ }^{2}$ Pharmaceutical Biology Research Group, School of Pharmacy, Bandung Institute of Technology, Indonesia. Email: dwintha_85@yahoo.co.id

Received: 23 June 2016, Revised and Accepted: 22 July 2016

ABSTRACT

Objective: The objective of this research was to evaluate the reduction of blood cholesterol level by fraction extracts of binahong (Anredera cordifolia) on male Wistar rats.

Methods: The rats were given high-fat food every day for 3 months and pure cholesterol on week $0,3,7$, and 11 . After that, each binahong fraction (n-hexane fraction, ethyl acetate fraction, and water fraction) with doses of $50 \mathrm{mg} / \mathrm{kg} \mathrm{bw}, 100 \mathrm{mg} / \mathrm{kg} \mathrm{bw}$, and $200 \mathrm{mg} / \mathrm{kg}$ bw was given orally for 3 weeks and observed for lipid profile on day 21.

Results: The result showed that n-hexane, ethyl acetate, and water fractions of binahong leaves decreased total cholesterol, triglyceride, and low-density lipoprotein (LDL) level and did not influence the high-density lipoprotein (HDL) level. Meanwhile, statin decreased total cholesterol, triglyceride, and LDL level and increased HDL level.

Conclusion: Ethyl acetate fraction of binahong leaves significantly reduced total cholesterol level, triglycerides, and LDL level compared to the negative control group $(\mathrm{p}<0.05)$ and had no influence in HDL level.

Keywords: Cardiovascular, Anredera cordifolia, Cholesterol.

(C) 2016 The Authors. Published by Innovare Academic Sciences Pvt Ltd. This is an open access article under the CC BY license (http://creativecommons org/licenses/by/4. 0/) DOI: http://dx.doi.org/10.22159/ajpcr.2016.v9i6.13628

\section{INTRODUCTION}

Cardiovascular disease (CVD) is a major cause of disabilityand premature death worldwide. The underlying pathology is atherosclerosis, which develops over many years and is usually advanced by the time symptoms occur, generally in middle age. Acute coronary events (heart attacks) and cerebrovascular events (strokes) frequently occur suddenly and are often fatal before medical care is given. Risk factor modification can reduce clinical events and premature death in people with established CVD as well as in those who are at high cardiovascular risk due to one or more risk factors [1]. Low-density lipoprotein cholesterol (LDL-C) is a key modifiable risk factor in the development of CVD. In 2012, the Japan Atherosclerosis Society (JAS) issued guidelines recommended statin as the first-line pharmacotherapy for lowering LDL-C in patients with high risk for cardiovascular [2]

Atherosclerosis is a complex pathological process in the walls of blood vessels that develops over many years. In atherosclerosis, fatty material and cholesterol are deposited inside the lumen of medium and large blood vessels (arteries). These deposits (plaques) cause the inner surface of the blood vessels become irregular and the lumen is narrow, so that blood was harder for flowing through [3].

Atherosclerotic CVD is the leading cause of death worldwide. Despite extraordinary advances in understanding of pathophysiology and utilization of very effective medications such as statin, there still remains a significant residual risk. In fact, even after optimal interventional and medical therapy, the possibility of recurrent myocardial infarction remains at approximately one-third in 5 years after acute coronary syndromes, thus emphasizing the urgent need for novel therapies to prevent the progress of atherosclerosis [3].

One of the plants that has benefits in treating many diseases was binahong (Anredera cordifolia [Ten.] Steenis) [4]. Organs of this plants that can be used were leaves, stems, roots, and flowers, in which leaves are most often used as herbal medicine. This plant is actually derived from China under the name Dheng san chi [5].
Atherosclerosis is a disease presented by thickening of arteries, which is in the beginning at the endothelial cells. The complication related to atherosclerosis which influence blood supply to the brain, then can cause stroke [6].

The objective of this research was to evaluate the reduction in blood cholesterol level of fraction extracts of binahong (A. cordifolia) on male Wistar rats.

\section{METHODS}

\section{Materials}

Leaves of binahong (A. cordifolia), amyl alcohol, ammonium, aquadest, hydrochloric acid, sulfuric acid, sodium carboxymethyl cellulose, ethanol, n-hexane, ethyl acetate, water, gelatin, chloroform, pure cholesterol, vanillin liquid in sulfuric acid, sodium oxide, propylthiouracil, statin, bismuth nitrate, potassium iodide, mercuric chloride, acetic anhydride, reagent kit for cholesterol, triglyceride, highdensity lipoprotein (HDL), and LDL.

\section{Plant preparation}

Leaves of A. cordifolia were collected from Lembang - Bandung Indonesia, were thoroughly washed with tap water, sorted while wet, cut, dried, and ground into powder. The plant was identified in Herbarium Bandungense, School of Life Science and Technology, Bandung Institute of Technology, Indonesia. A crude drug was extracted by reflux using ethanol $96 \%$, and then fractionated was conducted by liquid-liquid extraction using n-hexane and ethyl acetate, so there were 3 fractions: n-hexane, ethyl acetate, and water fractions.

\section{Experimental animals}

Experiments were performed with the approval by the Animal Research Ethics Committee of ITB (No. 02/KEPHP-ITB/11-2014). Male Wistar rats weighed 200-250 g and aged approximately 3 months.

\section{Phytochemical screening}

Phytochemical screening of crude drug, ethanolic extract, n-hexane, ethyl acetate, and water fraction of binahong (A. cordifolia) leaves was 
performed to determine the presence of saponin, quinone, flavonoid, tannin, alkaloid, and steroid/triterpenoid group [7].

\section{Animal models for endothelial fat content}

Animals were induced by high cholesterol feed which contained $1 \%$ cholesterol, $5 \%$ duck egg yolk, fat goat $10 \%, 1 \%$ coconut oil, and $83 \%$ standard feed, for 12 weeks, which on week $0,3^{\text {rd }}, 7^{\text {th }}$, and $11^{\text {th }}$ the rats were given pure cholesterol orally. After that, they were being prepared for 21 days administration of test extract. Then, the animals were divided into five groups, which were statin group (simvastatin $3.6 \mathrm{mg} / \mathrm{kg} \mathrm{bw}$ ), n-hexane, ethyl acetate, and water fractions of binahong leaves with doses of $50 \mathrm{mg} / \mathrm{kg}$ bw (the first dose), $100 \mathrm{mg} / \mathrm{kg} \mathrm{bw}$ (the second dose), $200 \mathrm{mg} / \mathrm{kg}$ bw (the third dose), and negative control group (matrix).

\section{RESULTS}

This research was started by phytochemical screening of crude drug, extract, and fractions of binahong leaves. The result of phytochemical screening could be seen in Table 1 .

The percentage of decreasing in total cholesterol could be seen in Fig. 1. The third dose of ethyl acetate fraction gave the highest percentage of decreasing in total cholesterol compared to the other doses.

In Fig. 2, it could be seen that the percentage of decreasing in total triglyceride of the third dose of ethyl acetate fraction of binahong leaves was the highest compared to the other doses.

The percentage of decreasing in total LDL could be seen in Fig. 3, which denoted that the third dose of ethyl acetate fraction gave the highest percentage of decreasing in total LDL compared to the other doses.

The percentage of increasing in total HDL could be seen in Fig. 4, which exposed that the highest increasing in total HDL was given by the third dose of ethyl acetate fraction of binahong leaves compared to the first dose and the second dose.

\section{DISCUSSION}

In the previous studies expressed that binahong (A. cordifolia) leaves had multiple biological effects such as antibacterial [8], antifungal [9], antihyperuricemic [10], hematoma [11], anti-inflammatory [12-14], and improving kidney failure in rats [15]. Urmila stated that methanol extract of Basella alba leaves which was the same family with binahong (A. cordifolia) had hyperlipidemia effect [16]. Research by Juwita et al. [17] demonstrated that leaves of binahong (A. cordifolia) could be used to manage the risk factors of hypertension and hypercholesterolemia which led to the coronary heart diseases. The acute and subchronic toxicity study of ethanol binahong extract by Salasanti [18] reported that the extract was safe.

The goals of this research were to evaluate the effect of binahong leaves fractions in cholesterol in male Wistar rats 200-250 g. The modified method [6] from previous research [19] was used in the present research. On the week $0,3^{\text {rd }}, 7^{\text {th }}$, and $11^{\text {th }}$, the rats were induced by pure

Table 1: Phytochemical screening of crude drug, extract, and fractions of binahong leaves

\begin{tabular}{|c|c|c|c|c|c|}
\hline Group & $\begin{array}{l}\text { Crude } \\
\text { drug }\end{array}$ & $\begin{array}{l}\text { Ethanol } \\
\text { extract }\end{array}$ & $\begin{array}{l}\text { n-hexane } \\
\text { fraction }\end{array}$ & $\begin{array}{l}\text { Ethyl acetate } \\
\text { fraction }\end{array}$ & $\begin{array}{l}\text { Water } \\
\text { fraction }\end{array}$ \\
\hline Saponin & + & + & + & + & + \\
\hline Quinone & - & - & - & - & - \\
\hline Flavonoid & + & + & + & + & + \\
\hline Tannin & - & - & - & - & - \\
\hline Alkaloid & + & + & + & + & + \\
\hline $\begin{array}{l}\text { Steroid/ } \\
\text { triterpenoid }\end{array}$ & + & + & + & + & + \\
\hline
\end{tabular}

+: detected, -: not detected cholesterol orally for 7 days with high cholesterol feed. The induction of cholesterol is to accelerate increasing in cholesterol level and optimize the cholesterol level. Then, the extract sample was given for 3 weeks.

Based on Fig. 1, it could be seen that all of the groups could reduce the total cholesterol and there were significantly different with the negative control group $(\mathrm{p}<0.05)$. Ethyl acetate fraction had significantly different with statin while $\mathrm{n}$-hexane and water fractions showed significant difference with statin $(\mathrm{p}<0.05)$. The result demonstrated that ethyl acetate fraction from ethanol leaves extract of binahong was very efficient in reducing of total cholesterol level. In the negative control group, the total cholesterol level also decreased 57.1\%, it might be due to its high cholesterol feed was replaced by normal feed. Based on this data, it can be concluded that by diet only, the total cholesterol level would decrease slowly by itself. It was similar to the previous researches which denoted that $96 \%$ ethanol leaves extract of binahong (A. cordifolia) [20] and methanol leaves extract of B. alba [21] could



Fig 1: Percentage of decreasing in total cholesterol. *Significantly different to negative control $(p<0.05)$

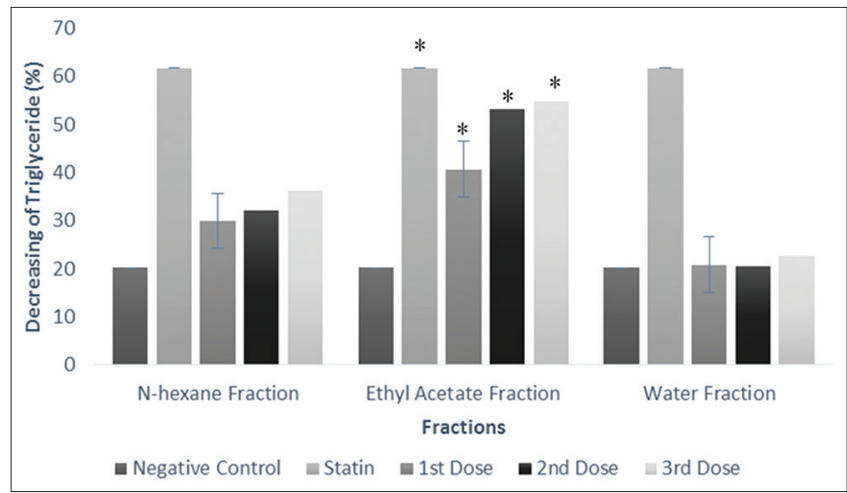

Fig. 2: Percentage of decreasing in triglyceride. *Significantly different to negative control $(p<0.05)$

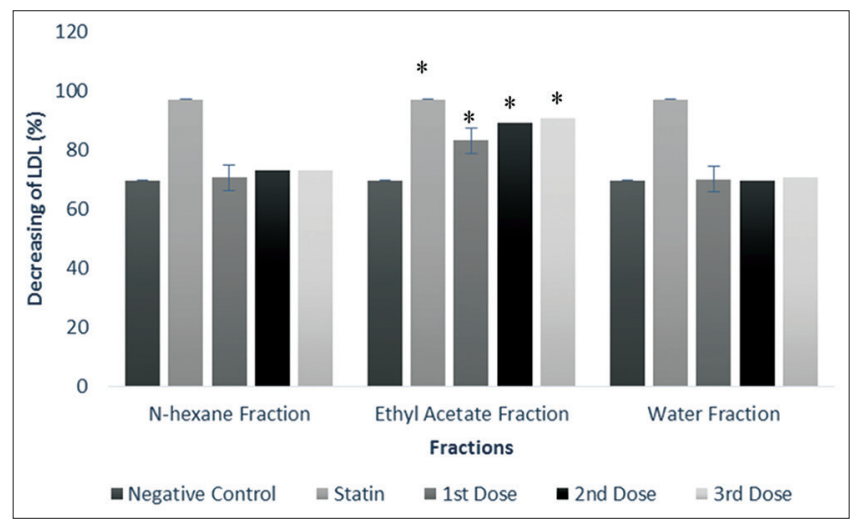

Fig. 3: Percentage of decreasing in low-density lipoprotein. $*$ Significantly different to negative control $(\mathbf{p}<0.05)$ 




Fig. 4: Percentage increasing in high-density lipoprotein. ${ }^{*}$ Significantly different to negative control $(\mathbf{p}<0.05)$

reduce cholesterol blood level, and also $A$. cordifolia leaves extract as reducer in anti-hyperlipidemia and endothelial fat in Wistar rats [6].

Increasing in endothelial nitric oxide (NO) synthase by LDL could increase NO and can cause damage endothelial cell [18]. Research by Fungwe [19] found that addition of cholesterol in diet is contributed to increase total cholesterol in plasma and LDL plasma.

In addition to the total cholesterol, all of the groups also showed significant reduction in triglycerides compared to the negative control group ( $\mathrm{p}<0.05$, Fig. 2). Ethyl acetate fraction of binahong leaves showed similar level with statin group in reduction of triglycerides, and had no significant difference with statin. The ethyl acetate fraction from ethanol leaves extract of binahong (A. cordifolia) with doses of $50 \mathrm{mg} / \mathrm{kg}$ bw until $200 \mathrm{mg} / \mathrm{kg}$ bw were effective to reduce triglycerides level, and it was different from n-hexane and water fractions. The negative control group also gave the reduction in triglycerides level due to the replacement of high cholesterol feed with the normal feed. It was similar to the previous research which exposed that ethanolic leaves extract of binahong had anti-hyperlipidemia effect [6].

All groups of ethyl acetate fractions with doses of $50 \mathrm{mg} / \mathrm{kg}$ bw, $100 \mathrm{mg} / \mathrm{kg}$ bw, and $200 \mathrm{mg} / \mathrm{kg}$ bw and statin group also showed a different level of reduction in LDL, and there was significant difference among the four groups. It was a similar result to Lestari's study [6] which showed that ethanolic leaves extract of binahong could reduce LDL level. Nevertheless, ethyl acetate fraction of binahong (A. cordifolia) leaves $50 \mathrm{mg} / \mathrm{kg} \mathrm{bw}, 100 \mathrm{mg} / \mathrm{kg} \mathrm{bw}$, and $200 \mathrm{mg} / \mathrm{kg}$ bw still have potential to reduce LDL level, and it was significantly different from n-hexane and water fractions $(p<0.05)$. The significant reduction of LDL was presented by all of the groups compared to the negative control group ( $<<0.05$, Fig. 3).The negative control group also showed a reduction of LDL level $29.06 \%$ which might be caused by the same factors as before.

Statin could increase HDL level 9.86\% while the other groups included ethyl acetate fraction showed only slightly increasing in HDL level. This result supports the previous study that $A$. cordifolia leaves ethanol extract could act as anti-hyperlipidemia [6].

\section{CONCLUSION}

Ethyl acetate fraction of binahong leaves with doses of $50 \mathrm{mg} / \mathrm{kg}$ bw, $100 \mathrm{mg} / \mathrm{kg} \mathrm{bw}$, and $200 \mathrm{mg} / \mathrm{kg}$ bw reduced total cholesterol level, triglycerides, LDL level significantly different compared to the negative control group ( $\mathrm{p}<0.05)$, and had no influence in the HDL level.

\section{REFERENCES}

1. WHO. Prevention of Cardiovascular Disease Pocket Guidelines for Assessment and Management of Cardiovascular Risk. Geneva: WHO; 2007. p. 1.

2. Teramoto T, Uno K, Miyoshi I, Khan I, Gorcyca K, Sanchez RJ, et al. Low-density lipoprotein cholesterol levels and lipid-modifying therapy prescription patterns in the real world: An analysis of more than 33,000 high cardiovascular risk patients in Japan. Atherosclerosis 2016;251:248-54.

3. Medis S, Puska P, Norving B, editors. Global Atlas on Cardiovascular Disease Prevention and Control. Geneva: WHO; 2011. p. 3.

4. Paju N, Yamlean PV, Kojong N. Effectiveness binahong leaf extract ointment (Anredera cordifolia (Ten) Steenis) test in rabbits (Oryctolagus cuniculus) were infected with the bacteria Staphylococcus aureus. Sci J Pharm 2013;2(1):51-61.

5. Manoi F, Balittro. Binahong (Anredera cordifolia) as a drug. Ind Crops Res Dev 2009;15(1):3-5.

6. Lestari D, Sukandar EY, Irda F. Anredera cordifolia leaves extract as an anti-hyperlipidemia and endothelial fat content reducer in wistar rat. Int J Pharm Clin Res 2015;7(6):435-9.

7. Ministry of Health Republic of Indonesia. Materia Medika Indonesia. Vol. 6. Jakarta: Ministry of Health Republic of Indonesia; 1995 p. 333-7.

8. Souza LF, de Barros IB, Mancini E, De Martino L, Scandolera E, De Feo V. Chemical composition and biological activities of the essential oil from Anredera cordifolia grown in Brazil. Nat Prod Commun 2014;9(7):1003-6.

9. Indriyanti N, Adnyana IK, Sukandar EY. Study of antifungal activity of binahong Anredera cordifolia and roots of Petiveria alliacea, Thesis. Bandung: School of Pharmacy - Bandung Institute of Technology; 2011.

10. Winarti W, Soemardji AA, Fidrianny I. Antihyperuricemia Effect of Ethanol Extract of Binahong (Anredera cordifolia) Leaves in Male Swiss Webster Mice Strain, Thesis. Bandung: School of Pharmacy Bandung Institute of Technology; 2011.

11. Sumartiningsih S. The effect of binahong to hematoma. World Acad Sci Eng Technol 2011;5:679-81.

12. Lin CC, Sung TC, Yen MH. The anti-inflammatory and liver protective effects of Boussingaultia gracilis var. Pseudo baselloides extract in rats. Phytother Res 199;8:201-7.

13. Saénz MT, García MD, Fernández MA. Anti-inflammatory activity and acute toxicity of Anredera leptostachys. Phytomedicine 1998;5(3):195-8.

14. Tornos MP, Saenz MT, Garcia MD, Fernandez MA. Antinociceptive effects of the tubercles of Anredera leptostachys. J Ethnopharmacol 1999;68(1-3): 229-34.

15. Sukandar EY, Fidrianny I, Adiwibowo LF. Efficacy of ethanol extract of Anredera cordifolia (Ten) steenis leaves on improving kidney failure in rats. Int J Pharmacol 2011;7(8):850-5.

16. Urmila GH, Satyanarayana T, Rao BG. Antihyperlipidemic activity of methanolic leaf extract of three different plants on high cholesterol diet induced hyperlipidemic rats. Int J Preclin Pharm Res 2014;5(1):30-3.

17. Juwita R, Sukandar EY, Fidrianny I, Patonah. Anti-Hyperlipidemia Effect of Ethanol Extract of Binahong (Anredera cordifolia) Leaves to Male Wistar Rats by Cholesterol Homeostatis Method, Thesis. Bandung: School of Pharmacy - Bandung Institute of Technology; 2011.

18. Salasanti CD, Sukandar EY, Fidrianny I. Acute and sub chronic toxicity study of ethanol extract of Anredera cordifolia (Ten.) v. Steenis leaves. Int J Pharm Pharm Sci 2014;6(5):348-52.

19. Hasimun P, Sukandar EY, Adnyana IK, Tjahjono DH. A simple method for screening antihyperlipidemic agents. Int $\mathrm{J}$ Pharmacol 2011;7(1):74-8.

20. Shaul PW. Endothelial nitric oxide synthase, caveolae and the development of atherosclerosis. J Physiol 2003;547(1):21-33.

21. Fungwe TV, Cagen L, Wilcox HG, Heimberg M. Regulation of hepatic secretion of very low density lipoprotein by dietary cholesterol. J Lipid Res 1992;33(2):179-91. 